\title{
Optimization of extraction and estimation of viruses in silty freshwater sediments
}

\author{
Ulrike R. Fischer, Alexander K. T. Kirschner, Branko Velimirov* \\ Research Group General Microbiology, Center for Anatomy \& Cell Biology, Medical University of Vienna, \\ Waehringer Strasse 10, 1090 Vienna, Austria
}

\begin{abstract}
The present study focused on the optimization of procedures for the extraction of viruses from silty freshwater sediments for subsequent enumeration. Viral abundance in 2 different shallow backwater systems of the River Danube (Austria) ranged from $1.45 \times 10^{9}$ to $9.58 \times 10^{9}$ particles $\mathrm{ml}^{-1}$ wet sediment. The highest virus yields from the bulk of the sediments were obtained by 1 min sonication $(3 \times 20 \mathrm{~s}$ intervals, with $10 \mathrm{~s}$ interruptions $)$. An increase in sonication time of up to $5 \mathrm{~min}$ decreased viral counts by an average of $15 \%$. Since dissolved DNA within sediment samples could bind to the nucleic acid stain and thereby inflate viral estimates, sediment samples are often treated with DNase before the staining procedure. Moreover, they are usually centrifuged and diluted to a high extent in order to avoid interference of particulate material with virus counting. Centrifugation led to a reduction of viral numbers by 2 to $36 \%$ compared to untreated samples and did not reduce the background fluorescence; thus counting of viruses was not facilitated. Diluting $2000 \times$ with MilliQ water always provided an average of $19 \%$ lower viral numbers than diluting $4000 \times$. Treatment with DNase had no significant effect on virus counting, with viral numbers in untreated samples being on average $96 \%$ of those in DNase-containing samples. Additionally, 2 different nucleic acid stains were compared - viruses stained with SYBR Gold fluoresced brighter than those stained with SYBR Green I and fluorescence lasted longer, while background fluorescence was reduced sufficiently, thus facilitating virus counting. Viral numbers using SYBR Gold were on average twice of those obtained with SYBR Green I. The mean efficiency of virus extraction was $88.8 \%$ using the protocol outlined in this paper, and was thus slightly higher than that obtained in previous sediment investigations.
\end{abstract}

KEY WORDS: Virus extraction - Virus counting - Epifluorescence microscopy - Silty freshwater sediment

\section{INTRODUCTION}

In freshwater and marine environments, viruses are the most numerous component of plankton, with abundances ranging from $10^{4}$ to $10^{8}$ viruses $\mathrm{ml}^{-1}$ (Wommack $\&$ Colwell 2000). Through infection and lysis, viruses exert a direct effect on the mortality of heterotrophic bacterioplankton, cyanobacteria and phytoplankton (Fuhrman 1999, Wilhelm \& Suttle 1999, Wommack \& Colwell 2000). They also play a role in biogeochemical cycling and control of host-species diversity (Fuhrman 1999, Wilhelm \& Suttle 1999).
The study of viruses in aquatic systems requires a reliable method for estimating the levels of these biological entities. The available methods for the determination of viral abundance in aquatic systems include counting by transmission electron microscopy (TEM) (Bergh et al. 1989, Børsheim et al. 1990), by flow cytometry (Chen et al. 2001, Brussaard 2004) and epifluorescence microscopy (EFM) (Hara et al. 1991, Hennes \& Suttle 1995, Xenopoulos \& Bird 1997, Noble \& Fuhrman 1998). The latter technique allows rapid enumeration, avoiding the use of expensive equipment necessary for estimation by TEM or flow cytometry. 
Moreover, EFM yields higher and more precise viral counts than TEM (Hennes \& Suttle 1995, Weinbauer \& Suttle 1997, Noble \& Fuhrman 1998). Enumeration of viruses by EFM is based on using highly fluorescent nucleic acid dyes such as DAPI (Hara et al. 1991, Weinbauer \& Suttle 1997), Yo-Pro I (Hennes \& Suttle 1995, Xenopoulos \& Bird 1997), SYBR Green I (Noble \& Fuhrman 1998) or SYBR Gold (Chen et al. 2001).

Viral abundance in sediment systems is 10 - to 1000 fold higher than in the overlying water column (e.g. Maranger \& Bird 1996, Steward et al. 1996, Drake et al. 1998, Hewson et al. 2001, Lawrence et al. 2002, Fischer et al. 2003, Hewson \& Fuhrman 2003). Studies using EFM to estimate viruses in sediments applied a variety of protocols, without testing whether the procedures carried out before enumeration (e.g. virus dislodgement from particles, centrifugation, dilution) affect viral counts (Danovaro \& Serresi 2000, RicciardiRigault et al. 2000, Danovaro et al. 2001, 2002, Fischer et al. 2003, 2004, Hewson \& Fuhrman 2003, Hewson et al. 2003, Middelboe et al. 2003, Mei \& Danovaro 2004). A single study aimed at designing a protocol for determination of benthic viral numbers was done only on marine sediments (Danovaro et al. 2001); freshwater systems were completely neglected. An added complication in the enumeration of naturally occurring benthic viral populations is the uncertainty as to whether differences in extractability of viruses among different sediment types exist. Hence, it would be useful to test whether the protocol designed for virus enumeration in marine sediments is adaptable to freshwater sediments, and to which extent improvements of the methodology are required.

Within the frame of a long-term study on the carbon flow between the compartments of the microbial loop in the oxygenated layer of silty sediments of backwater systems (Fischer et al. 2003, 2004, Wieltschnig et al. $2003 a, b)$, it was of primordial importance to consider the viral loop. Protocols on virus extraction and estimation in silty freshwater sediments are so far lacking, yet silty sediments are a frequent feature of most aquatic habitats with moderate or little water disturbance such as deep lakes, sheltered lakes, alluvial forests and oxbow lakes (Fenchel et al. 1998, Wetzel 2001). The present study was executed to optimize the EFM enumeration of viruses in silty freshwater sediments. We focused our attention on (1) virus dislodgement from particles (the first step in any analysis of benthic viruses is effective extraction from the sediment) (2) effect of centrifugation of samples (to remove coarse sediment particles and facilitate virus counting), (3) extent of dilution of sediment samples necessary to avoid interference of particulate material with virus counting, (4) the possible falsification of virus counts caused by extracellular DNA, and (5) the com- parison of the commonly used nucleic acid stain SYBR Green I with SYBR Gold.

\section{MATERIALS AND METHODS}

Study site and sample collection. Samples were taken from the Kühwörther Wasser and the Alte Donau, 2 shallow (mean water depth 1 and $3.5 \mathrm{~m}$, respectively) backwater systems of the River Danube, Austria. The investigated sites were characterized by muddy sediments consisting of 2 to $6 \%$ medium to coarse sand $(\geq 250 \mu \mathrm{m}), 6$ to $14 \%$ fine sand (125 to $<250 \mu \mathrm{m}), 25$ to $33 \%$ very fine sand (63 to $<125 \mu \mathrm{m})$, 42 to $63 \%$ silt $(2$ to $<63 \mu \mathrm{m})$, and $5 \%$ clay $(<2 \mu \mathrm{m})$. Sediment cores were collected between August 2000 and May 2001 by hand-coring using Plexiglas tubes (inner diameter $5.8 \mathrm{~cm}$, penetration depth 15 to $20 \mathrm{~cm}$ ). The top $0.5 \mathrm{~cm}$ of the sediment of 5 cores was pooled by gentle mixing with a stirring magnet. Sediment parameters (bulk density, water content, organic matter content) were determined as described by Kirschner \& Velimirov (1999). Porosity was calculated from the water content and bulk density of the sediment. Water content varied from 73 to $86 \%$, porosity from 0.77 to 0.87 , and organic matter content from 16.7 to $21.8 \mathrm{mg} \mathrm{ml}^{-1}$ fresh weight. Since the sampling sites were similar as to granulometry, bulk density, porosity, water content and organic matter content, the results have been combined.

To establish a protocol for virus counting in silty freshwater sediments, aliquots (1 g) of the sediment slurry were diluted with $30 \mathrm{ml}$ Milli-Q water, and fixed with electron microscopy-grade glutaraldehyde (3\% final concentration). Samples were kept at $4{ }^{\circ} \mathrm{C}$ in the dark until processing, which was always performed within $24 \mathrm{~h}$. Since storage of aldehyde-fixed samples at $4^{\circ} \mathrm{C}$ reduces viral numbers (Xenopoulos \& Bird 1997, Marie et al. 1999, Danovaro et al. 2001), even within the initial $24 \mathrm{~h}$ period of fixation (Brussaard 2004, Wen et al. 2004), the viral counts in the present study may be underestimates. All samples that are compared were processed simultaneously. They were treated with $0.02 \mu \mathrm{m}$-filtered sodium-tetrapyrophosphate for at least $20 \mathrm{~min}$. A low final concentration of $5 \mathrm{mM}$ was used in order to minimize the extraction of humic acids (Maranger \& Bird 1996). Moreover, the use of high pyrophosphate concentrations makes the optical field opalescent under the EFM, thus complicating virus counting (Danovaro et al. 2001).

Comparison of SYBR Green I and SYBR Gold viral counts. The original SYBR Green I and SYBR Gold stock solutions $(10000 \times$ concentrate in DMSO, Molecular Probes) were diluted with autoclaved Milli-Q water to final concentrations of 1 and $0.25 \%$. Sediment 
samples were sonicated for $1 \mathrm{~min}(3 \times 20 \mathrm{~s}$, with $10 \mathrm{~s}$ interruptions) at $70 \mathrm{~W}$ using a Branson Sonifier 450 (Branson Ultrasonics Corporation), and diluted (4000×) with Milli-Q water. Aliquots (1 ml) were then filtered through $0.02 \mu \mathrm{m}$ pore-size $\mathrm{Al}_{2} \mathrm{O}_{3}$ Anodisc membrane filters backed by a $0.2 \mu \mathrm{m}$ pore-size cellulose nitrate filter at approximately $20 \mathrm{kPa}$ vacuum. The Anodisc membranes were dried and laid sample-side up on a drop of the staining solution for $15 \mathrm{~min}$ in the dark (Noble \& Fuhrman 1998, Chen et al. 2001, Noble 2001). The filters were then dried and mounted on a glass slide with a drop of Citifluor (Glycerol/PBS solutionAF1; Agar Scientific) containing 0.1\% p-phenylenediamine (made freshly from a frozen 10\% aqueous stock; Sigma Aldrich Chemie). All preparations were done under subdued light. Filters were examined at a magnification of $1250 \times$ with a Leica DMRB microscope (Leica) equipped with an HBO $50 \mathrm{~W}$ mercury lamp (excitation wavelength 450 to $490 \mathrm{~nm}$, cut-off filter $515 \mathrm{~nm}$ ). Total counts of 30 to 50 randomly selected fields usually exceeded 200 viruses per subsample. The inventory of viruses from bulk sediment included particle-adsorbed viruses as well as viruses in pore water. Viral numbers are expressed as 'particles $\mathrm{ml}^{-1}$ wet sediment'.

Virus dislodgement. Sediment samples were sonicated for $0,1,2,3,4$, and $5 \mathrm{~min}$ at $70 \mathrm{~W}$. To prevent overheating, sonication was at intervals of $20 \mathrm{~s}$ with $10 \mathrm{~s}$ interruptions. Additionally, after samples were treated $3 \times$ for $20 \mathrm{~s}$, sonication was interrupted for 5 min, during which time the samples were kept on ice. After further dilution, viral numbers were estimated as described in the foregoing subsection.

Centrifugation time. After sonication, samples were centrifuged (Sigma Laboratory Centrifuge 3K30, fixedangle rotor No. 12156, Sigma Laborzentrifugen) under different conditions: at $1000 \times g$ for 30 and $5 \mathrm{~min}$; at 500 and $200 \times g$ for $5 \mathrm{~min}$; at 400 and $800 \times g$ for $1 \mathrm{~min}$ (Gerba et al. 1977, LaBelle \& Gerba 1982, Tsai et al. 1983, Chalapati Rao et al. 1984, Hu 1998, Danovaro et al. 2001, 2002). The supernatant was further diluted, and viruses in the supernatant were counted.

Dilution of sediment samples. Sediment samples were sonicated and subsequently diluted $2000 \times$ or $4000 \times$ with Milli-Q water, before virus counting.

DNase-test. Aliquots (1 g) of the sediment slurry were diluted, treated with pyrophosphate and sonicated; 250 Kunitz units of DNase I from bovine pankreas (Sigma) were added to $1 \mathrm{ml}$ aliquots and incubated for $30 \mathrm{~min}$ at room temperature (Suttle 1993). Additional aliquots (1 ml) without DNase were incubated under the same conditions and served as controls. After fixation with glutaraldehyde, sonication and further dilution, the viruses in samples containing DNase and in untreated samples were counted. To confirm the DNase-digested DNA in water from the Kühwörther Wasser, its activity was assayed following the protocol of Drake et al. (1998): 250 Kunitz units of DNase were added to $40 \mu \mathrm{g} \mathrm{ml}^{-1}$ DNA (Type I, 'highly polymerized' from calf thymus, Sigma) in water samples. The temporal change in absorbance at $260 \mathrm{~nm}$ within $10 \mathrm{~min}$, monitored using a Hitachi U-2000 spectrophotometer (Hitachi), was $0.002 \mathrm{~min}^{-1}$ (data not shown).

Virus extraction efficiency. A known amount of viruses concentrated from the water column of the study sites by ultrafiltration (Noble \& Fuhrman 1999) was added to samples (1 g) of the sediment slurry (= virus-amended samples), and shaken at $250 \mathrm{rpm}$ for $30 \mathrm{~min}$ at room temperature to allow adsorption of viruses to sediment particles (Gerba et al. 1977, LaBelle \& Gerba 1979, Tsai et al. 1983). After fixation with glutaraldehyde, treatment with pyrophosphate, sonication and further dilution, viruses were counted by EFM. Extraction efficiency was determined by dividing virus counts in virus-amended sediment by the sum of counts in unamended sediment samples plus counts of the virus ultrafiltration-concentrate (= control), and multiplying this ratio by 100 .

Statistical analysis. For the computation of correlations between data, we used Spearman's rho correlation. For analysis of variance, the nonparametric Mann-Whitney $U$-test was applied according to Zar (1974). In all statistical analyses, probabilities of $\leq 0.05$ and $\leq 0.01$ were considered significant and highly significant, respectively. We used SPSS version 10.0.8 (SPSS) software.

\section{RESULTS AND DISCUSSION}

\section{Viral abundance}

Following our protocol (see Fig. 6), the viral numbers in the sediment systems investigated varied from $1.45 \times 10^{9}$ to $9.58 \times 10^{9}$ particles $\mathrm{ml}^{-1}$ wet sediment, and were thus in the same order of magnitude as those previously reported for sediments of aquatic environments, including marine (e.g. Danovaro \& Serresi 2000, Hewson et al. 2001, Danovaro et al. 2002) and freshwater (e.g. Maranger \& Bird 1996, RicciardiRigault et al. 2000, Fischer et al. 2003, 2004) sediments.

\section{Comparison of SYBR Green I and SYBR Gold viral counts}

SYBR Gold has so far been used to stain viruses in samples from the water column (McDaniel et al. 2001, Yager et al. 2001, Williamson et al. 2002, Anesio et al. 


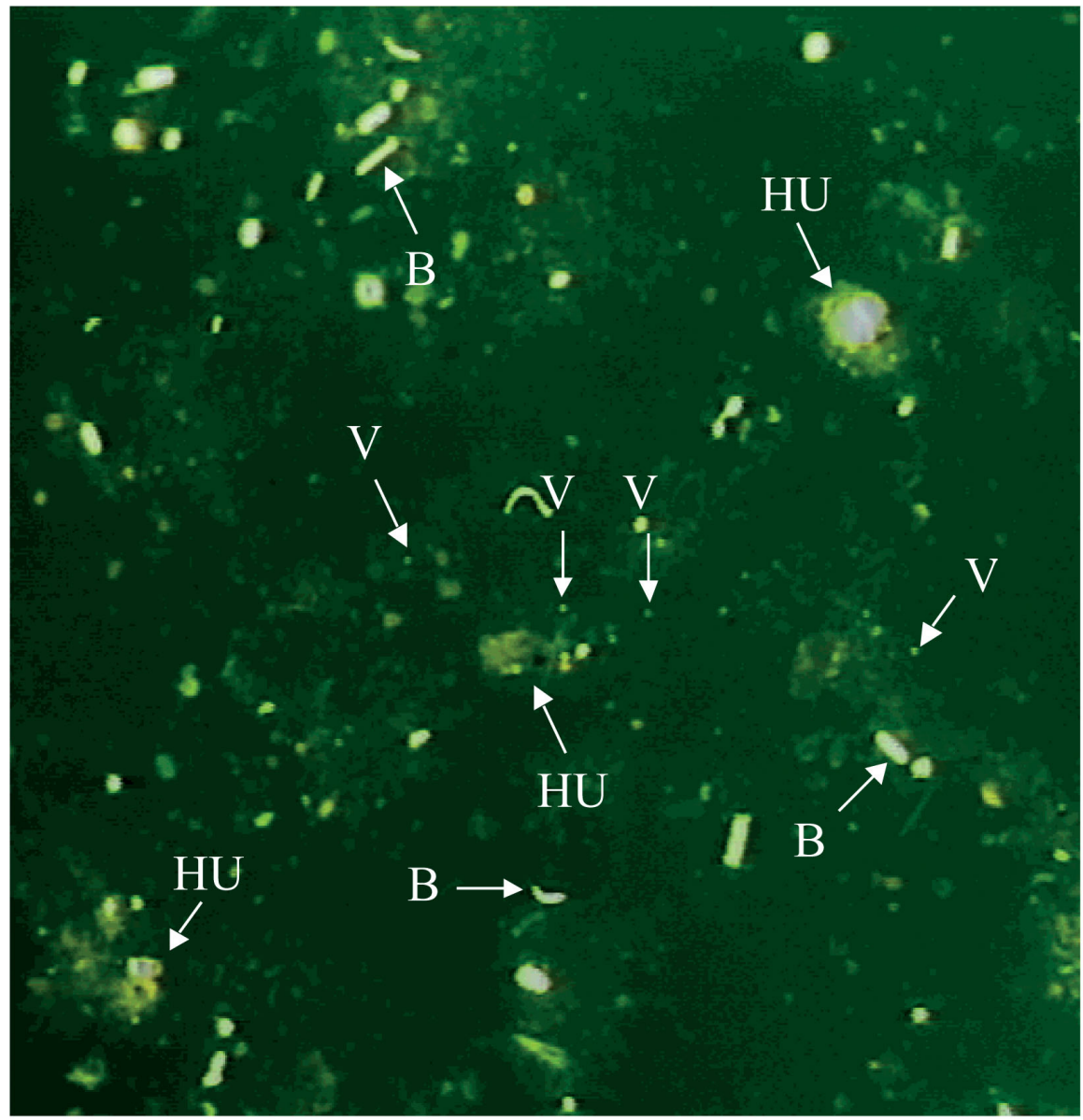

Fig. 1. SYBR Gold (0.25\% final concentration)-stained sample from silty freshwater sediment filtered onto a $0.02 \mu \mathrm{m}$ pore-size membrane. The larger bright yellow-green particles are considered to be bacteria (B), the smaller particles viruses (V). Bacteria and viruses are easily distinguishable from humic substances (HU). (Leica DMRB microscope and Kappa CF 15/4 MCC camera)

2004, Breitbart et al. 2004, Brussard 2004, Lisle \& Priscu 2004, Wen et al. 2004) and sediment (Fischer et al. 2003, 2004) of aquatic systems, in soil samples (Williamson et al. 2003) and human feces (Breitbart et al. 2003). Direct comparison of staining viruses with SYBR Gold and the commonly used dye SYBR Green I has been made in 4 studies: (1) Chen et al. (2001) reported that even when no antifading-solution was used, the fluorescence of SYBR Gold-stained viruses in marine water samples was stable for more than $2 \mathrm{~min}$ under EFM, while the SYBR Green I signal faded within $30 \mathrm{~s}$. Using flow cytometry to enumerate Cyanophage P49, the mean fluorescence per P49 virus determined with SYBR Gold was about 2 times higher than that with SYBR Green I. However, Chen et al. (2001) did not directly compare viral counts with SYBR Gold and SYBR Green I by EFM in their investigation. (2) This also applies to the study of Brussaard (2004), who used flow cytometry to examine a variety of different pelagic viruses, including representatives of phyto- plankton viruses, cyanobacteriophages, coliphages, marine bacteriophages and natural mixed marine virus communities stained with SYBR Green I and SYBR Gold. The use of SYBR Gold resulted in slightly lower green fluorescence signals of the stained viruses. No significant effect was recorded for the total virus counts when all tested viruses were taken into account, but for some of the individual viruses and a natural sample, staining with SYBR Gold resulted in reduced total counts compared to staining with SYBR Green I. (3) Using EFM, Wen et al. (2004) found that staining with SYBR Green I and SYBR Gold yielded apparently identical numbers of pelagic viruses. (4) The only attempt to compare the ability of different nucleic acid dyes to stain viruses in sediment samples was by Hewson \& Fuhrman (2003), who counted marine benthic viruses by EFM using SYBR Green I, SYBR Green II and SYBR Gold. They made only a brief comment that the emission color of SYBR Green II and SYBR Gold was close to that of autoflourescent humic materials in 
sediments, and could not be used easily for benthic virus counts. Unfortunately, Hewson \& Fuhrman (2003) did not detail the results of virus estimates with the different stains. For routine virus counting in marine sediments, they used SYBR Green I.

In the present study, viruses in sediment samples stained with SYBR Gold yielded a bright and stable yellow-green fluorescence under the EFM (Fig. 1). The brightness of the SYBR Gold signal varied, likely due to different viral genome sizes among viruses (Chen et al. 2001). Viral particles could be easily distinguished from bacteria by their relative size and shape. In comparison with SYBR Green I, the fluorescence of SYBR Gold-stained viruses was not only brighter, but also lasted longer, while background fluorescence was reduced sufficiently, thus facilitating virus counting.

For dilution of the stain stock solutions, we used the standard protocol of Noble \& Fuhrman (1998) and Noble (2001), who recommended increasing the concentration of SYBR Green I usually used $\left(2.5 \times 10^{-3}\right.$ dilution of the stock solution, i.e. final concentration of $0.25 \%$ ) for samples of specific environments, i.e. when the viruses did not stain brightly. We diluted both the stock solution of SYBR Green I and SYBR Gold to a final concentration of 1 and $0.25 \%$, respectively, and compared the resultant viral counts (Fig. 2). SYBR Green Icounts at different dye concentrations did not differ significantly ( $p>0.90, n=9$ ), and the precision of the counts was similar, with an average coefficient of variation (CV) for triplicate samples of $30 \pm 12 \%$ versus $26 \pm$ $10 \%$. In contrast, counts for different dye concentra- tions of SYBR Gold differed significantly $(\mathrm{p}<0.05, \mathrm{n}=$ 9). Viral numbers estimated after staining with the $1 \%$ SYBR Gold-solution were on average only $56 \pm 5 \%$ of those obtained with the $0.25 \%$ solution. The results of the 2 concentrations were correlated $(p<0.05, n=9)$. At first sight, it seems paradoxical that a higher concentration of the SYBR Gold dye yielded lower viral counts; because of the brighter fluorescence signal of the viruses, one would expect more accurate counts. However, a $1 \%$ final concentration of SYBR Gold also led to very brightly stained bacterial cells, and the resultant fluorescent halos around these cells as well as the higher background fluorescence obtained with samples stained with $1 \%$ SYBR Gold probably masked the fluorescence of the stained viruses, resulting (at least partly) in lower counts. Brussard (2004) also reported reduced viral abundance at high dye concentrations ( 0.005 to $0.01 \%$ dilution of commercial stock solution of SYBR Green I for counting viruses by flow cytometry).

Direct comparison of SYBR Green I-virus counts with SYBR Gold-counts revealed that the results of the 2 methods were correlated $(p<0.05, n=9)$. However, staining with SYBR Gold yielded significantly higher viral numbers ( $p<0.05, n=9$ ), implying that staining viruses with SYBR Green I led to underestimation of benthic viral abundance. Virus estimates using SYBR Gold at 1 and $0.25 \%$ final concentrations were, respectively, $1.5 \pm 0.20$ and $2.7 \pm 0.45$ times higher than those obtained with SYBR Green I. Also, SYBR Gold-counts were more precise, with an average CV of $16 \pm 3 \%$ for the $1 \%$ solution and $8 \pm 1 \%$ for the $0.25 \%$ solution, respectively, compared to SYBR Green I CVs of $30 \pm 12$ and $26 \pm 10 \%$. As mentioned at the beginning of this subsection, Wen et al. (2004) found no difference in pelagic viral counts using SYBR Green I and SYBR Gold. However, they used a very high concentration of both dyes (4\% final concentration of original stock solution), and the present investigation has shown that the difference between viral counts using SYBR Green I and SYBR Gold is lower when the dyes are diluted to a final concentration of only $1 \%$ compared to $0.25 \%$.

Based on our results, we recommend the use of SYBR Gold nucleic acid stain diluted to a final concentration of $0.25 \%$ for routine virus estimation in sediments. Because of the high amount of detritus and the presence of sediment particles, virus counting in sediment samples is more difficult than counting of pelagic viruses. The

Fig. 2. Virus counts in silty freshwater sediments using 2 different nucleic acids stains and epifluorescence microscopy. The stains (SYBR Green I and SYBR Gold) were used at 2 dilutions of stock solution (1 and $0.25 \%$ final concentration). Results of 3 replicate experiments. Mean \pm SD of triplicate samples 
stability and brightness of SYBR Gold fluorescence combined with the reduced background fluorescence represents a distinct advantage for the enumeration of benthic viruses by EFM. Moreover, SYBR Gold is a sensitive fluorescence stain for detecting double- and single-stranded DNA and RNA, whereas SYBR Green I is a fluorochrome mainly useful for detecting doublestranded DNA. The manufacturer (Molecular Probes) claims that it can also be used to detect single-stranded DNA and RNA; but its sensitivity is lower than for double-stranded DNA. This may have partly contributed to the difference between the SYBR Green I- and SYBR Gold counts. Another advantage of SYBR Gold is that the price is only half that of SYBR Green I.

\section{Virus dislodgement}

The use of pyrophosphate as an eluent to dislodge viruses from particles is well established (e.g Lawrence et al. 2002, Hewson \& Fuhrman 2003, Hewson et al. 2003), and in some studies sediment samples have been additionally sonicated (e.g. Maranger \& Bird 1996, Danovaro \& Serresi 2000, Danovaro et al. 2001, 2002, Mei \& Danovaro 2004). Middelboe et al. (2003) reported that the addition of sodium pyrophosphate significantly increased dislodgement of viruses from marine sediment relative to untreated samples, and that the application of sonication treatment further increased the release of viruses. The efficiency of their combined pyrophosphate-sonication treatment was 65 to $78 \%$ of the total extractable viruses.

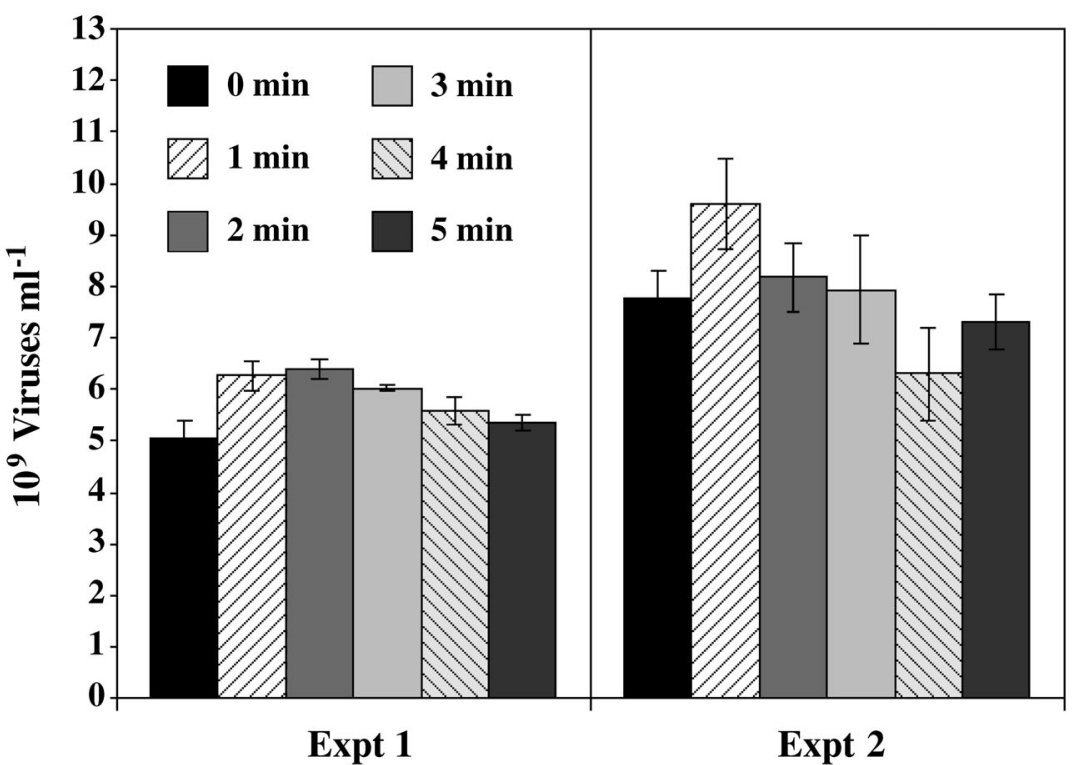

Fig. 3. Effect of sonication on virus counts in silty freshwater sediments. Results of 2 replicate experiments. Mean \pm SD of triplicate samples
Despite the fact that investigations on viruses in sediments are becoming more frequent, to our knowledge only a single study has been conducted to determine the optimal sonication time: Danovaro et al. (2001) sonicated muddy and sandy marine sediments for $0,1,3,8$ and $15 \mathrm{~min}$. The highest viral counts were obtained after 3 min sonication, and these values were significantly higher than values obtained without sonication. A further increase in sonication time decreased viral counts. However, virus sorption usually increases with increasing cation concentration in solution, particularly in the presence of divalent cations (Schijven \& Hassanizadeh 2000, Jin \& Flury 2002). Therefore, the protocol design for the extraction of benthic viruses from marine sediments may not be applicable to freshwater sediments. The present study thus aimed at detecting the optimal sonication time for the extraction of viruses from silty freshwater sediments. Highest viral counts were obtained after 1 min sonication, being on average $19 \pm 8 \%$ higher than without sonication (Fig. 3). This difference was statistically significant $(\mathrm{p}<0.03, \mathrm{n}=6)$. Viral counts after 2 and 3 min sonication were on average $94 \pm 10 \%$ and $89 \pm 9 \%$ of counts obtained after sonicating for $1 \mathrm{~min}(\mathrm{p}>0.20, \mathrm{n}=6)$. Further increases in sonication time further decreased virus estimates, and sonication for $4 \mathrm{~min}$ or longer reduced virus counts significantly $(\mathrm{p}<0.05, \mathrm{n}=6)$, with an average of $79 \pm 11 \%$ of viral numbers detected after 1 min sonication. The $\mathrm{CV}$ was always low, ranging between 3 and $14 \%$. From the trend observed during the experiments, we believed that higher viral counts after sonication $>5$ min would be very improbable; therefore we aborted the experiments, and a sonication time of 1 min was used in all further experiments.

When using sonication to dislodge viruses from sediment particles, it must be taken into account that this procedure may cause disruption of virus-infected bacterial cells, releasing mature viral particles, and thus falsifying the number of free viruses originally present in the sample. Assuming a production of $22.2 \times 10^{7}$ viruses $\mathrm{ml}^{-1}$ $\mathrm{h}^{-1}$ (maximum value for viral production measured previously in one of the backwater systems investigated; Fischer et al. 2003), we calculated that even if all viruses theoretically produced within $1 \mathrm{~h}$ were to be set free from infected cells during the sonication step, viral abundance would on average be overestimated by a factor of only 1.029 (range 1.021 to 1.038). Disruption of virus-infected bacteria 
did thus not drastically falsify the numbers of free viruses counted in the present study.

\section{Centrifugation time}

The presence of sediment particles on the Anodisc filters complicates virus counting. Therefore, sediment samples have usually been centrifuged prior to virus estimation by EFM (e.g. Drake et al. 1998, Danovaro et al. 2001, 2002, Hewson et al. 2001, 2003, Lawrence et al. 2002, Hewson \& Fuhrman 2003, Middelboe et al. 2003), under the assumption that this process does not remove viruses, and hence does not falsify viral counts. However, none of these studies tested whether this assumption is valid. Our experiments revealed that centrifugation of sediment samples led to an average of $15 \pm 14 \%$ lower viral counts compared to untreated samples (Fig. 4). The difference in viral abundance was significant $(\mathrm{p}<0.05, \mathrm{n}=3)$ in 2 cases $(1000 \times g$ for $30 \mathrm{~min}$ : $36 \%$ lower counts; and $200 \times g$ for $5 \mathrm{~min}: 32 \%$ lower counts). Only centrifugation of samples at $800 \times$ $g$ for $1 \mathrm{~min}$, as carried out by Danovaro et al. (2001, 2002), gave values similar to those of untreated samples. An average of $98 \%$ of viruses counted in untreated samples were present after centrifugation. However, in subsequent experiments we did not centrifuge samples prior to virus counting because centrifugation at $800 \times g$ for 1 min did not reduce the background fluorescence, and thus virus counting was not facilitated. Moreover, counts of untreated samples were slightly more precise than counts of centrifuged samples, as indicated by a CV of $11 \%$ (average CV of

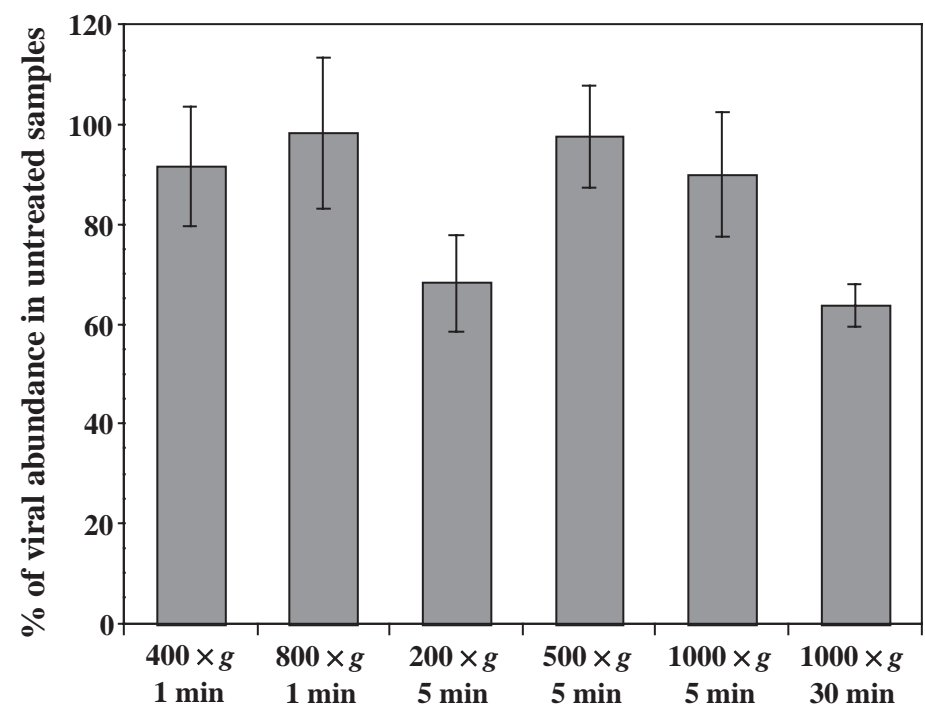

Fig. 4. Effect of centrifugation on virus counts in silty freshwater sediments. Mean \pm SD of replicate samples $(n=3$ for 1000 and $200 \times g, 6$ for 400 and $800 \times g, 9$ for $500 \times g$ ) all untreated samples of the different centrifugation experiments) versus $14 \%$ for centrifuged samples. The opposite trend would be expected since untreated samples should be more heterogenous (i.e. contain more particles) than centrifuged samples. We have no explanation for the higher precision of counts in untreated samples.

\section{Dilution of sediment samples}

To avoid interference of particulate material with virus counting, and to obtain an optimal number of viruses per microscopic field (15 to 30 ), it is necessary to dilute sediment samples to a high extent. We diluted samples by $2000 \times$ and $4000 \times$, and compared viral counts. The $2000 \times$ dilution always produced significantly lower viral numbers $(\mathrm{p}<0.05, \mathrm{n}=6$ ) than the $4000 \times$ dilution (data not shown). Virus estimates after $2000 \times$ dilution $\left(4.1 \times 10^{9}\right.$ to $5.3 \times 10^{9}$ particles $\left.\mathrm{ml}^{-1}\right)$ were on average only $81 \pm 13 \%$ of those for $4000 \times$ diluted samples $\left(5.0 \times 10^{9}\right.$ to $7.4 \times 10^{9}$ particles $\left.\mathrm{ml}^{-1}\right)$. The precision of the $4000 \times$ dilution (CV $12 \%$ ) was less than that of the $2000 \times$ dilution (CV 6\%). However, since naturally occurring viruses were being extracted, the best extraction was considered to be achieved by the method giving the highest yield of viruses. In subsequent experiments, we thus diluted sediment samples $4000 \times$.

\section{DNase test}

It is conceivable that dissolved DNA within sediment samples could bind to SYBR Gold and thereby inflate viral estimates. In order to eliminate uncertainties in virus counting due to extracellular DNA interference, we tested the effect of DNase treatment on silty freshwater sediment samples. Virus estimates for untreated samples were $96 \pm 4 \%$ of those for samples to which DNase had been added (Fig. 5). The results for the 2 protocols were positively correlated ( $p<0.01, n=12)$. Since the difference was not statistically significant $(p>$ $0.60, \mathrm{n}=12$ ), we omitted the addition of DNase in further experiments. Drake et al. (1998), who enumerated viruses in the pore water of marine sediments, obtained similar results. In contrast, Danovaro et al. (2001) detected significantly higher viral counts after DNase treatment of marine sandy sediments, and suggested that virus counting was facilitated in these samples through the reduction in fluorescence noise caused by extracellular DNA bound to the fluorochrome. Nevertheless, DNase should be used with caution, since it has repeatedly been reported to affect viral particles, consequently falsifying viral counts: (1) Using TEM, 


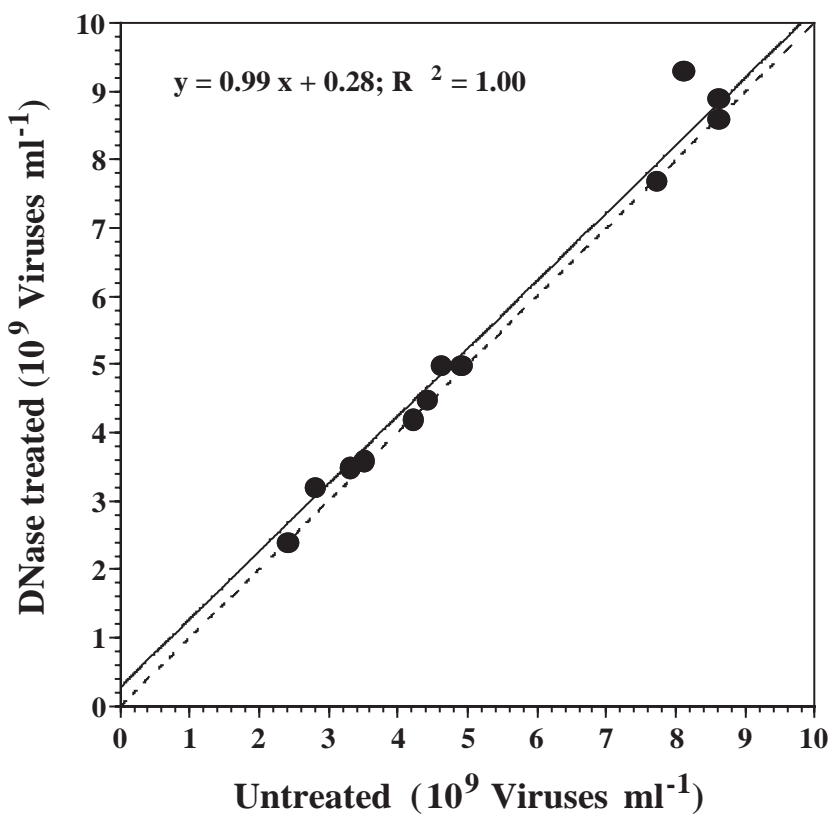

Fig. 5. Virus counts in silty freshwater sediment samples treated with DNase versus virus counts in untreated samples. Continuous line: Type II regression; dashed line indicates relationship of $1: 1$

Bettarel et al. (2000) recorded a significant reduction in viral numbers in freshwater samples of $19 \%$ after DNase treatment; (2) in a culture containing T2-phages and marine plankton samples, 33 to $48 \%$ of the encapsulated viral DNA were sensitive to DNase (Jiang \& Paul 1995); (3) some $10 \%$ of the $<0.2 \mu \mathrm{m}$ fraction of DNA in marine water samples, which was assumed tocomprise viruses (i.e. 'coated DNA'), was digested by DNase (Maruyama et al. 1993). To what extent these observations are also valid for sediment samples is unknown. Before enzymes are routinely used for virus counting in EFM protocols for a particular sediment system, virus counts in untreated samples should be compared with those of DNase-treated samples using TEM, to ensure that DNase addition does not falsify viral counts.

\section{Virus extraction efficiency}

Viral counts of virus-amended samples (i.e. sediment samples to which a known amount of viruses concentrated from the water column had been added and then extracted following the protocol of the present study) did not differ significantly from the control (i.e. the sum of counts in untreated sediment samples plus counts of the virus concentrate) $(\mathrm{p}>0.10, \mathrm{n}=6)$; mean efficiency of virus extraction was $88.8 \pm 11.8 \%$ (range 67.5 to $101.6 \%$ ). In comparison, the treatment of sediment samples with pyrophosphate and sonication in other studies led to a virus extraction efficiency of 60 to $78 \%$, which was tested by washing the sediment samples 2 or 3 times with Milli-Q water and virus-free seawater, respectively, after initial elution (Danovaro et al. 2001, Middelboe et al. 2003). A virus extraction efficiency of $85 \%$ in the initial elution step was achieved by treating sediment samples with an elution buffer consisting of pyrophosphate, EDTA and formaldehyde alone (without sonication), followed by 3 successive washes with the elution buffer (Hewson \& Fuhrman 2003). However, the effect of sonication was not tested.

Extraction efficiency in the present study was higher than that in previous investigations, but nevertheless $11.2 \%$ of the added viruses were not extractable, probably because they were too firmly attached to sediment particles. Assuming that the extraction efficiency of the added and subsequently adsorbed viruses is a realistic reflection of the adsorption behavior of viruses in natural sediment samples, we therefore underestimated the benthic viral population by some $11 \%$.

Thus, our protocol allows assessment of the fraction of 'non-extractable' viruses, whereas that used by other authors (washing the sediment samples several times, see above) does not provide any information on the virus fraction that may still remain resistant to the extraction procedure even after several washing steps.

A schematic overview of the protocol we recommend for counting viruses in silty freshwater sediments is given in Fig. 6.

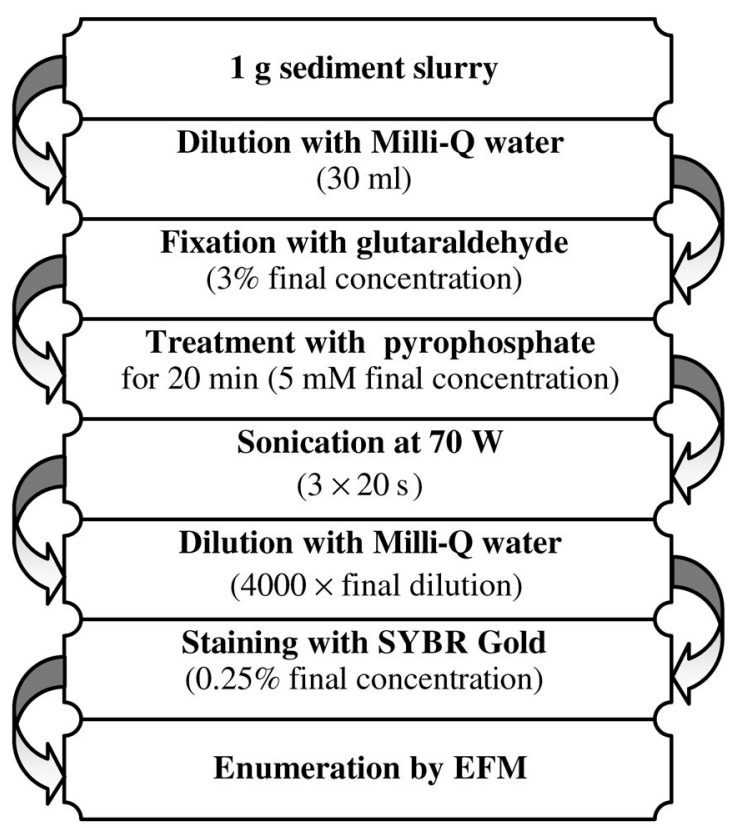

Fig. 6. Virus extraction from silty freshwater sediments and enumeration by epifluorescence microscopy (EFM). Note that uncertainties in virus counting due to extracellular DNA interference should be eliminated before estimation of benthic viruses by EFM (see 'Results and discussion') 
Acknowledgements. This study was financed by the Austrian Fonds zur Förderung der Wissenschaftlichen Forschung (FWF), Projects No. P14220-BIO and No. P17246-B03. We are grateful to C. Wieltschnig (Medical University of Vienna, Center for Anatomy \& Cell Biology, Research Group General Microbiology, Austria) for field assistance and constructive comments on the manuscript. Thanks to C. Mössler (Medical University of Vienna, Center for Anatomy \& Cell Biology, Research Group General Microbiology, Austria) for her aid in obtaining digital images of SYBR Gold-stained viruses, and B. Luef (University of Vienna, Department of Limnology, Austria) for helpful discussion on virus staining procedures.

\section{LITERATURE CITED}

Anesio AM, Hollas C, Granéli W, Laybourn-Parry J (2004) Influence of humic substances on bacterial and viral dynamics in freshwaters. Appl Environ Microbiol 70: 4848-4854

Bergh O, Børsheim KY, Bratbak G, Heldal M (1989) High abundance of viruses found in aquatic environments. Nature 340:467-468

Bettarel Y, Sime-Ngando T, Amblard C, Laveran H (2000) A comparison of methods for counting viruses in aquatic systems. Appl Environ Microbiol 66:2283-2289

Børsheim KY, Bratbak G, Heldal M (1990) Enumeration and biomass estimation of planktonic bacteria and viruses by transmission electron microscopy. Appl Environ Microbiol 56:352-356

Breitbart M, Hewson I, Felts B, Mahaffy JM, Nulton J, Salamon P, Rohwer F (2003) Metagenomic analyses of an uncultered viral community from human feces. J Bacteriol 185:6220-6223

Breitbart M, Wegley L, Leeds S, Schoenfeld T, Rohwer F (2004) Phage community dynamics in hot springs. Appl Environ Microbiol 70:1633-1640

Brussaard M (2004) Optimization of procedures for counting viruses by flow cytometry. Appl Environ Microbiol 70: 1506-1513

Chalapati Rao VC, Seidel KM, Goyal SM, Metcalf TG, Melnick JL (1984) Isolation of enteroviruses from water, suspended solids, and sediments from Galveston Bay: survival of poliovirus and rotavirus adsorbed to sediments. Appl Environ Microbiol 48:404-409

Chen F, Lu J, Binder BJ, Liu Y, Hodson RE (2001) Application of digital image analysis and flow cytometry to enumerate marine viruses stained with SYBR Gold. Appl Environ Microbiol 67:539-545

Danovaro R, Serresi M (2000) Viral density and virus-tobacterium ratio in deep-sea sediments of the Eastern Mediterranean. Appl Environ Microbiol 66:1857-1861

Danovaro R, Dell'Anno A, Trucco A, Serresi M, Vanucci S (2001) Determination of virus abundance in marine sediments. Appl Environ Microbiol 67:1384-1387

Danovaro R, Manini E, Dell'Anno A (2002) Higher abundance of bacteria than of viruses in deep Mediterranean sediments. Appl Environ Microbiol 68:1468-1472

Drake LA, Choi KH, Haskell AGE, Dobbs FC (1998) Vertical profiles of virus-like particles and bacteria in the water column and sediments of Chesapeake Bay, USA. Aquat Microb Ecol 16:17-25

Fenchel T, King GM, Blackburn TH (1998) Bacterial biogeochemistry: the ecophysiology of mineral cycling. Academic Press, San Diego, CA

Fischer UR, Wieltschnig C, Kirschner AKT, Velimirov B (2003) Does viral-induced lysis contribute significantly to bacter- ial mortality in the oxygenated sediment layer of shallow oxbow lakes? Appl Environ Microbiol 69:5821-5289

Fischer UR, Weisz W, Wieltschnig C, Kirschner AKT, Velimirov B (2004) Benthic and pelagic viral decay experiments: a model-based analysis and its applicability. Appl Environ Microbiol 70:6706-6713

Fuhrman JA (1999) Marine viruses and their biogeochemical and ecological effects. Nature 399:541-548

Gerba CP, Smith EM, Melnick JL (1977) Development of a quantitative method for detecting enteroviruses in estuarine sediments. Appl Environ Microbiol 34:158-163

Hara S, Terauchi K, Koike I (1991) Abundance of viruses in marine waters: assessments by epifluorescence and transmission electron microscopy. Appl Environ Microbiol 57: 2731-2734

Hennes KP, Suttle CA (1995) Direct counts of viruses in natural waters and laboratory cultures by epifluorescence microscopy. Limnol Oceanogr 40:1050-1055

Hewson I, Fuhrman JA (2003) Viriobenthos production and virioplankton sorptive scavenging by suspended particles in coastal and pelagic waters. Microb Ecol 46:337-347

Hewson I, O'Neil JM, Fuhrman JA, Dennison WC (2001) Virus-like particle distribution and abundance in sediments and overlying waters along eutrophication gradients in two subtropical estuaries. Limnol Oceanogr 46: 1734-1746

Hewson I, Vargo GA, Fuhrman JA (2003) Bacterial diversity in shallow oligotrophic marine benthos and overlying waters: effects of virus infection, containment, and nutrient enrichment. Microb Ecol 46:322-336

Hu TL (1998) A comparison of two methods to recover phages from soil samples. Bioresour Technol 65:167-169

Jiang SC, Paul JH (1995) Viral contribution to dissolved DNA in the marine environment as determined by differential centrifugation and kingdom probing. Appl Environ Microbiol 57:2197-2204

Jin Y, Flury M (2002) Fate and transport of viruses in porous media. Adv Agron 77:39-64

Kirschner AKT, Velimirov B (1999) Benthic bacterial secondary production measured via simultaneous ${ }^{3} \mathrm{H}$-thymidine and ${ }^{14} \mathrm{C}$-leucine incorporation, and its implication for the carbon cycle of a shallow macrophyte-dominated backwater system. Limnol Oceanogr 44:1871-1881

LaBelle RL, Gerba CP (1979) Influence of $\mathrm{pH}$, salinity and organic matter on the adsorption of enteric viruses to estuarine sediment. Appl Environ Microbiol 38:93-101

LaBelle RL, Gerba CP (1982) Investigations into the protective effect of estuarine sediment on virus survival. Water Res 16:469-478

Lawrence JE, Chan AM, Suttle CA (2002) Viruses causing lysis of the toxic bloom-forming alga Heterosigma akashiwo (Raphidophyceae) are widespread in coastal sediments of British Columbia, Canada. Limnol Oceanogr 47:545-550

Lisle JT, Priscu JC (2004) The occurrence of lysogenic bacteria and microbial aggregates in the lakes of the McMurdo Dry Valleys, Antarctia. Microb Ecol 47:427-439

Maranger R, Bird DF (1996) High concentrations of viruses in the sediments of Lac Gilbert, Quebec. Microb Ecol 31: 141-151

Marie D, Brussaard CPD, Thyrhaug R, Bratbak G, Vaulot D (1999) Enumeration of marine viruses in culture and natural samples by flow-cytometry. Appl Environ Microbiol 65:45-52

Maruyama A, Oda M, Higashihara T (1993) Abundance of virus-sized non-DNase-digestible DNA (coated DNA) in eutrophic seawater. Appl Environ Microbiol 59:712-717 
McDaniel L, Griffin DW, Crespo-Gomez J, McLaughlin MR, Paul JH (2001) Evaluation of marine bacterial lysogens for development of a marine prophage induction assay. Mar Biotechnol 3:528-535

Mei ML, Danovaro R (2004) Virus production and life strategies in aquatic systems. Limnol Oceanogr 49:459-470

Middelboe M, Glud RN, Finster K (2003) Distribution of viruses and bacteria in relation to diagenetic activity in an estuarine sediment. Limnol Oceanogr 48:1447-1456

Noble RT (2001) Enumeration of viruses. Methods Microbiol 30:43-50

Noble RT, Fuhrman JA (1998) Use of SYBR Green I for rapid epifluorescence counts of marine viruses and bacteria. Aquat Microb Ecol 14:113-118

Noble RT, Fuhrman JA (1999) Breakdown and microbial uptake of marine viruses and other lysis products. Aquat Microb Ecol 20:1-11

Ricciardi-Rigault M, Bird DF, Prairie YT (2000) Changes in sediment viral and bacterial abundances with hypolimnetic oxygen depletion in a shallow eutrophic Lac Brome (Quebec, Canada). Can J Fish Aquat Sci 57:1284-1290

Schijven JF, Hassanizadeh SM (2000) Removal of viruses by soil passage: overview of modeling, processes, and parameters. Crit Rev Environ Sci Technol 30:49-127

Steward GF, Smith DC, Azam F (1996) Abundance and production of bacteria and viruses in the Bering and Chukchi Seas. Mar Ecol Prog Ser 131:287-300

Suttle CA (1993) Enumeration and isolation of viruses. In: Kemp PF, Sherr BF, Sherr EB, Cole JJ (eds) Handbook of methods in aquatic microbial ecology. Lewis, Boca Raton, FL, p 121-134

Tsai SC, Ellender RD, Johnson RA, Howell FG (1983) Elution of viruses from coastal sediments. Appl Environ Microbiol 46:797-804

Weinbauer MG, Suttle CA (1997) Comparison of epifluorescence and transmission electron microscopy for counting

Editorial responsibility: Gunnar Bratbak,

Bergen, Norway viruses in natural marine waters. Aquat Microb Ecol 13: $225-232$

Wen K, Ortmann AC, Suttle CA (2004) Accurate estimation of viral abundance by epifluorescence microscopy. Appl Environ Microbiol 70:3862-3867

Wetzel RG (2001) Limnology. Lake and river ecosystems. Academic Press, San Diego, CA

Wieltschnig C, Fischer UR, Kirschner AKT, Velimirov B (2003a) Benthic bacterial production and protozoan predation in a silty freshwater environment. Microb Ecol 46: $62-72$

Wieltschnig C, Kirschner AKT, Fischer UR, Velimirov B (2003b) Top-down control of benthic heterotrophic nanoflagellates by oligochaetes and microcrustaceans in a littoral freshwater habitat. Freshw Biol 48:1840-1849

Wilhelm SW, Suttle CA (1999) Viruses and nutrient cycles in the sea-viruses play critical roles in the structure and function of aquatic food webs. BioScience 49:781-788

Williamson KE, Wommack KE, Radosevich M (2003) Sampling natural viral communities from soil for culture-independent analyses. Appl Environ Microbiol 69:6628-6633

Williamson SJ, Houchin LA, McDaniel L, Paul JH (2002) Seasonal variation in lysogeny as depicted by prophage induction in Tampa Bay, Florida. Appl Environ Microbiol 68:4307-4314

Wommack KE, Colwell RR (2000) Virioplankton: viruses in aquatic ecosystems. Microbiol Mol Biol Rev 64:69-114

Xenopoulos MA, Bird DF (1997) Virus a la sauce Yo-Pro: microwave-enhanced staining for counting viruses by epifluorescence microscopy. Limnol Oceanogr 42:1648-1650

Yager PL, Connelly TL, Mortazavi B, Wommack KE, Bano N, Bauer JE, Opsahl S, Hollibaugh JT (2001) Dynamic bacterial and viral response to an algal bloom at subzero temperatures. Limnol Oceanogr 46:790-801

Zar JH (1974) Biostatistical analysis. Prentice-Hall, Englewood Cliffs, NJ

Submitted: March 22, 2005; Accepted: June 29, 2005

Proofs received from author(s): October 12, 2005 